Marquette University

e-Publications@Marquette

Economics Faculty Research and Publications

Business Administration, College of

$1-1-1997$

\title{
Optimal Sterilization Policies in Interdependent Economies
}

Joseph Daniels

Marquette University, joseph.daniels@marquette.edu

Accepted version. Journal of Economics and Business, Vol. 49, No. 1 (January 1997): 43-60.

DOI.Published under Creative Commons license Attribution-NonCommercial-NoDerivatives 4.0

International. 


\title{
Optimal Sterilization Policies in Interdependent Economies
}

\author{
Joseph Daniels \\ Department of Economics, Marquette University \\ Milwaukee, WI
}

In this paper, a two-country leader-follower model with imperfect asset substitution is used to derive the optimal sterilization coefficients for twocountry flexible and fixed exchange rate regimes. It is found that, in general, incomplete sterilization is optimal. However, both the origin and the type of macroeconomic shocks the economies experience are important in determining the appropriate degree of sterilization. We also find that sterilization policies have spill-over effects (strategic complements) in both cases. Thus, in a competitive policy-making environment, greater sterilization by one country leads to greater sterilization by the other country. Further, the impact of increasing capital market integration is examined in particular. We show that greater integration compounds this problem, leading to full sterilization as the optimal outcome under perfect capital mobility.

\section{Introduction}

Sterilization of foreign exchange operations is a significant feature of the monetary policies of the industrial countries. Indeed, routine sterilization is a well-known practice of the Federal Reserve Bank, the Bank of Japan, and the Bundesbank. Further, sterilization of 
other country interventions has also been practiced, in particular by Germany and France. Empirical studies confirm this for most countries, yielding estimates of a sterilization coefficient greater than zero but less than one, or full sterilization [Mastropasqua et al. (1988)]. Studies on the Bundesbank indicate near full, or not significantly different from full sterilization [Pasula (1994); von Hagen (1989); Obstfeld (1983)].

Herring and Marston (1977) have shown that though sterilization of foreign exchange operations can afford a degree of monetary autonomy for a country, it has important consequences for the stability of reserve flows. In addition, within an exchange rate agreement, sterilized intervention prevents the correction of domestic monetary policy and interest rate alignment necessary for stability of the system. Mastropasqua et al. (1988, p. 283) noted this problem and characterized EMS member policy making with "somewhat excessive reliance on sterilized interventions, on occasion with the aim of rigidly defending a particular exchange rate level, and insufficiently supportive use of domestic monetary instruments (interest rates)." Therefore the appropriate degree of sterilization is an important policymaking issue.

Though optimal foreign exchange intervention policy has received a great deal of attention in the professional literature [prominent articles include Gros and Lane (1992); Turnovsky (1985a, b); Black (1985); Benavie (1983); Canzoneri (1982); Boyer (1978)], the issue of appropriate sterilization policies is still somewhat unsettled. This is mainly because most traditional theoretical models assume perfect capital mobility and, therefore, sterilized foreign exchange intervention leaves the home country money supply unchanged and is ineffective.

As a result, one principal area of investigation centers on the channels by which sterilized intervention may affect the exchange market. There are two common approaches in which fully-sterilized intervention can be effective. One is an announcement approach in which there is asymmetric information or incomplete markets. Here, the central bank has superior information about economic fundamentals and signals this information to the public through its policy actions. The second approach is a portfolio approach, where 
assets are imperfect substitutes internationally, and sterilized intervention is effective by altering the relative supplies of these assets. Bordo and Schwartz (1991), and Dominguez and Frankel (1994) have provided summaries of this and related literature.

Another area of research, which is usually based on a portfolio approach, allows for variable sterilization and determines the optimal degree of sterilization and foreign exchange intervention. Examples here include Benavie and Froyen (1992), Natividad and Stone (1990), Kenen (1982), and Marston (1980). Only Marston has examined sterilization in a two-country setting, but this analysis does not include the real sector. Therefore, what is missing from the literature is a full analysis of the interaction of sterilization and intervention policies across countries. This paper attempts to fill this void.

In this paper, the optimal degree of sterilization is derived in a two-country framework, in which the policymakers attempt to minimize both the variance of home output (or home output prices) and the variance of consumer price inflation. The interaction of sterilization and intervention policies is then examined in this context. The theoretical model employed here allows for variable sterilization and is derived from asset models such as Canzoneri (1982) and Benavie (1983). As bonds are considered imperfect substitutes, even fully-sterilized intervention can affect the exchange rate.

The optimal sterilization and intervention settings are determined for two cases: a leader-intervention and a leader-fixedrate case. As in Lane (1989), a unique Nash solution does not exist for the selection of intervention by both countries. Thus, the leader country chooses its rule for intervention and the optimal degree of sterilization is determined, based on this rule. It is found that, in general, incomplete sterilization is optimal. However, both the origin and the type of macroeconomic shocks the economies experience are important in determining the appropriate degree of sterilization. We also find that sterilization policies have spill-over effects (strategic complements) in both cases. Thus, in a competitive policy making environment, greater sterilization by one country leads to greater sterilization by the other country, generating increased reserves instability. Further, the impact of increasing capital market integration

Journal of Economics and Business, Vol 49, No. 1 (January 1997): pg. 43-60. DOI. This article is (C) Elsevier and permission has been granted for this version to appear in e-Publications@Marquette. Elsevier does not grant permission for this article to be further copied/distributed or hosted elsewhere without the express permission from Elsevier. 
is examined in particular. We show that greater integration compounds this, leading to full sterilization under perfect capital mobility.

The following section presents and describes a two-country, variable sterilization model and provides solutions. In Section III, the interaction of sterilization and intervention policies is examined within this model. In Section IV, the optimal solutions are derived for a flexible rate example and in Section $\mathrm{V}$, for a fixed rate example. Section VI provides a summary and conclusion.

\section{A Model of Interdependent Economies}

Our results are derived from a model of two identical economies with bonds which are imperfect substitutes internationally. The model is typical of the literature, and the reader is referred to the smalleconomy examples of Benavie (1983) and Natividad and Stone (1990), and the multiple-country example of Canzoneri (1982).

\section{Model Equations}

The following eight-equation structure depicts the home and foreign markets for goods, money and bonds:

Consumer Prices

$$
\begin{aligned}
& c_{t} \equiv \alpha p_{t}+(1-\alpha)\left(p_{t}^{*}+e_{t}\right) ; \alpha>\frac{1}{2} \\
& c_{t}^{*} \equiv \alpha p_{t}^{*}+(1-\alpha)\left(p_{t}-e_{t}\right),
\end{aligned}
$$

Aggregate Demand

$$
\begin{aligned}
& \begin{aligned}
\gamma_{t} & =a_{l}\left(p_{t}^{*}+e_{t}-P_{t}\right)-a_{2}\left[r_{t}-\left(E_{t} c_{t+1}-c_{t}\right)\right]+\eta_{t} ; a_{1.2} \\
& >0
\end{aligned} \\
& \gamma_{t}^{*}=a_{1}\left(p_{t}^{*}+e_{t}-p_{t}\right)-a_{2}\left[r_{t}^{*}-\left(E_{t} c_{t+1}^{*}-c_{t}^{*}\right)\right]+\eta_{t}^{*}
\end{aligned}
$$

Journal of Economics and Business, Vol 49, No. 1 (January 1997): pg. 43-60. DOI. This article is @ Elsevier and permission has been granted for this version to appear in e-Publications@Marquette. Elsevier does not grant permission for this article to be further copied/distributed or hosted elsewhere without the express permission from Elsevier. 


\section{Aggregate Supply}

$$
\begin{aligned}
& y_{t}=a_{3}\left(p_{t}-E_{t-1}-p_{t}\right)+\rho_{t} ; a_{3} \geq 0, \\
& y_{t}^{*}=a_{3}\left(p_{t}^{*}-E_{t-1} p_{t}^{*}\right)+\rho_{t}^{*}
\end{aligned}
$$

\section{Money Demand}

$$
\begin{aligned}
& m_{t}-p_{t}=y_{t}-a_{4} r_{t}+\mu_{t} ; a_{4} \geq 0, \\
& m_{t}^{*}-p_{t}^{*}=y_{t}^{*}-a_{4} r_{t}^{*}+\mu_{t}^{*}
\end{aligned}
$$

\section{Bond Demand}

$$
\begin{aligned}
b_{t}=g_{1} r_{t}- & g_{2}\left[r_{t}^{*}+\left(E_{t} e_{t+1}-e_{t}\right)\right]+g_{3}\left(y_{t}+y_{t}^{*}\right)+g_{4} \xi_{t} \\
& -\mu_{t} ; g_{1,2,3,4}>0, \\
b_{t}^{*}=g_{1} r_{t}^{*} & -g_{2}\left[r_{t}-\left(E_{t} e_{t+1}-e_{t}\right)\right]+g_{3}\left(y_{t}+y_{t}^{*}\right)-g_{4} \xi_{t} \\
& -\mu_{t}^{*}
\end{aligned}
$$

\section{Money Supply Rules}

$$
\begin{aligned}
& m_{t}=m_{t-1}+\Delta f_{t}-\Delta f_{t}^{*}+\Delta d_{t} \\
& m_{t}^{*}=m_{t-1}^{*}+\Delta f_{t}^{*}-\Delta f_{t}+\Delta d_{t}^{*} \\
& \Delta f_{t}=-\theta_{1}\left(e_{t}+E_{t-1} e_{t}\right), \\
& \Delta f_{t}^{*}=\theta_{1}^{*}\left(e_{t}-E_{t-1} e_{t}\right), \\
& \Delta d_{t}=-\theta_{2}\left(\Delta f_{t}-\Delta f_{t}^{*}\right),
\end{aligned}
$$




$$
\Delta d_{t}^{*}=-\theta_{2}^{*}\left(\Delta f_{t}^{*}-\Delta f_{t}\right)
$$

where home (foreign) variables and policy parameters are non-asterisk (asterisk), with

$$
\begin{aligned}
& y_{t} \equiv \log \text { of real output, } \\
& p_{t} \equiv \log \text { of home output price level, } \\
& e_{t} \equiv \text { the log of the exchange rate, measured as units of domestic } \\
& \text { currency per unit of foreign currency, } \\
& m_{t} \equiv \log \text { of the nominal money stock, } \\
& r_{t} \equiv \log \text { of home output price level, } \\
& f_{t} \equiv \log \text { of the stock of foreign exchange reserves valued at a } \\
& \text { constant rate and denominated in a common accounting } \\
& \text { standard, } \\
& d_{t} \equiv \log \text { of domestic credit denominated in a common } \\
& \quad \text { accounting standard, } \\
& E_{t+j} \equiv \text { expectations operator, conditional on information dated } \\
& \text { time } t+j, \\
& \eta_{t} \equiv \text { home output demand disturbance, with } E\left(\eta_{t}=0\right) \text { and } \\
& \quad E\left(\eta_{t}\right)^{2}=\sigma_{\eta}^{2}, \\
& \rho_{t} \equiv \text { home output supply disturbance, with } E\left(\rho_{t}=0\right) \text { and } E\left(\rho_{t}\right)^{2}= \\
& \quad \sigma_{\rho}^{2}, \\
& \mu_{t} \equiv \text { exogenous home bond to home money portfolio shift, with } \\
& \quad E\left(\mu_{t}=0\right) \text { and } E\left(\mu_{t}\right)^{2}=\sigma_{\mu}^{2}, \\
& \xi_{t} \equiv \text { exogenous foreign bond to home bond portfolio shift, with } \\
& \quad E\left(\xi_{t}=0\right) \text { and } E\left(\xi_{t}\right)^{2}=\sigma_{\xi}^{2}, \\
& b_{t} \equiv \text { flow demand for home bonds, denominated in a common } \\
& \quad \text { accounting standard. }
\end{aligned}
$$

All variables are normalized around trend, and stochastic disturbances are assumed to be independent and uncorrelated.

Equations ( 1 ) and $\left(1^{*}\right)$ define the consumer price index for each economy, where a represents the weight on consumption of home goods. Equations (2) and $\left(2^{*}\right)$ are the equilibrium conditions for home output demand, where demand is positively related to home output price competitiveness and negatively related to the home real interest rate, computed by the home CPI. Equations (3) and (3*) are typical 
price-misperception aggregate supply functions. These supply functions could be based on consumer prices as opposed to home output price, adding feedback channels (via the exchange rate and foreign prices) and greater algebraic detail, but without changing our general conclusions. Therefore, for comparison with the literature cited in the introduction and at the beginning of this section, only home output price is included in the supply function.

Equations (4) and (4*) are the demand functions for real money balances in each economy. The income elasticity of money demand is assumed to be unity as a mere simplification which has no substantive impact on our results. Although the anticipated non-home interest rate could be included in equations (4) and ( $\left.4^{*}\right)$, this would add an additional feedback channel and greatly complicate the already burdensome algebra without affecting our general conclusions. The term represents an exogenous shift in home asset preferences, when positive, from home bonds to home money.

Equations (5) and (5*) are the demand flow functions for home and foreign bonds, where home (foreign) bond demand depends positively on the home (foreign) yield and negatively on the expected foreign (home) yield. Both home and foreign bonds are normal goods in that there is a positive relationship between demand and income. When positive, $\xi_{t}$ represents an exogenous portfolio shift from foreign bonds to home bonds. Branson and Henderson (1984) have provided a detailed explanation of the derivation of, and the assumptions inherent in, asset demand functions such as these. As a further assumption here, it is assumed that the interest elasticity of bond demand is greater than the interest elasticity of money demand. This assumption precludes an ambiguous exchange rate effect of money demand shocks.

Finally, equations (6) through ( $8^{*}$ ) represent the money supply rules. In equation (6), the home money supply is a function of systematic intervention by home and foreign authorities in the foreign exchange market and home sterilization, as reflected by changes in foreign reserves and domestic credit. If $\theta_{1}>0$, a depreciation of the home currency $\left[\left(e_{t}-E_{t} e_{t-1}\right)>0\right]$ leads the domestic authority to sell foreign reserves and the foreign authority to buy foreign reserves, 
e.g., leaning with the wind. Further, $\theta_{1}=\infty$ represents a fixed or pegged exchange rate regime; $\theta_{1}>0$, a flexible regime; and $0<\left|\theta_{1}\right|<$ $\infty$, a managed regime.

The exchange market intervention envisioned here is that in which the monetary authority intervenes simply by buying or selling the other country's currency (in effect, exchanging reserves). ${ }^{1}$ The intervention action of the foreign (home) authority is not necessarily immediately and fully sterilized by the home (foreign) authority, and thus affects the home (foreign) money supply. As an example, consider the case where $\theta_{1}=0, \theta_{1}^{*}>0$. If the home currency appreciates ( $e_{t}$ decreases), the foreign authority sells foreign reserves $\left(\Delta f_{t}^{*}<0\right)$. As shown in equations (6) and (6*), the foreign money supply decreases and the home money supply increases. Consequently, the money supplies are linearly dependent. The implication of this for optimal intervention solutions is addressed in greater detail later in the paper.

In equations ( 8$)$ and $\left(8^{*}\right)$, domestic credit is affected by the degree of sterilization, determined by the offset coefficients $\theta_{2}$ and $\theta_{2}^{*}$. If $\theta_{2}=1$, exchange market intervention is fully sterilized. If $\theta_{2}=0$, no sterilization is conducted and the home money supply responds to unanticipated exchange rate movements to a degree determined by the intervention parameters $\theta_{1}$ and $\theta_{1}^{*}$. Finally if $0<\theta_{2}<1$, the exchange market intervention is partially sterilized. Note that the exchange market intervention conducted by the foreign authority is not assumed to be automatically sterilized. Hence, intervention by the foreign authority affects the home money supply, and the home authority can use sterilization operations as an instrument even when the home authority does not conduct exchange market intervention.

Obviously, domestic credit could be conditioned upon a host of other variables, increasing the number of instruments available to the monetary authorities. However, the objectives of the monetary authorities could be increased as well. We choose here to focus specifically on exchange rate intervention and sterilization.

Journal of Economics and Business, Vol 49, No. 1 (January 1997): pg. 43-60. DOI. This article is (C Elsevier and permission has been granted for this version to appear in e-Publications@Marquette. Elsevier does not grant permission for this article to be further copied/distributed or hosted elsewhere without the express permission from Elsevier. 


\section{Equilibrium Conditions and Solutions}

For each country, the current account surplus less capital outflows equals changes in official reserves. Aggregating the balance of payments equations and ignoring interest rate effects on trade balances [as in Benavie (1983)], the external equilibrium condition, or difference between changes in official reserves, can be expressed as:

$$
\begin{aligned}
\Delta f_{t}-\Delta f_{t}^{*}= & h_{1}\left(p_{t}^{*}+e_{t}-p_{t}\right)+h_{2}\left(r_{t}-r_{t}^{*}\right)-h_{3}\left(E_{t} e_{t+1}-e_{t}\right)+\xi_{t} \\
& -\mu_{t}+\mu_{t}^{*}
\end{aligned}
$$

where $h_{1} \equiv 2 a_{1}, h_{2} \equiv 2\left(g_{1}+g_{2}\right), h_{3} \equiv 4 g_{2}$, and, for mere convenience, $g_{4}$ is assumed equal to one half. Note that if uncovered interest parity were to hold, $h_{2}$ and $h_{3}$ would approach infinity in value. In the bulk of our analysis, it is assumed that there is some degree of capital mobility, but uncovered interest parity does not hold.

The five equilibrium conditions can now be used to solve for the five endogenous variables, $r_{t}, r_{t}^{*}, p_{t}, p_{t}^{*}$, and $e_{t}$. Setting home (foreign) money demand equal to home (foreign) money supply (the $L M$ equation) yields expressions for $r_{t}\left(r_{t}^{*}\right)$. These expressions are substituted into the remaining three equilibrium conditions for the home goods market, foreign goods market, and the external equilibrium condition given in equation (9). Solutions are proposed for the remaining three endogenous variables:

$$
\begin{gathered}
p_{t}=\pi_{10}+\pi_{11} \eta_{t}+\pi_{11}^{*} \eta_{t}^{*}+\pi_{12} \rho_{t}+\pi_{12}^{*} \rho_{t}^{*}+\pi_{13} \mu_{t}+\pi_{13}^{*} \mu_{t}^{*}+ \\
\pi_{14} \xi_{t}+\pi_{15} m_{t-1}+\pi_{15}^{*} m_{t-1}^{*}, \\
p_{t}^{*}=\pi_{20}+\pi_{21} \eta_{t}+\pi_{21}^{*} \eta_{t}^{*}+\pi_{22} \rho_{t}+\pi_{22}^{*} \rho_{t}^{*}+\pi_{23} \mu_{t}+\pi_{23}^{*} \mu_{t}^{*}+ \\
\pi_{24} \xi_{t}+\mu_{25} m_{t-1}+\pi_{25}^{*} m_{t-1}^{*}, \\
e_{t}=\mu_{30}+\pi_{31} \eta_{t}+\pi_{31}^{*} \eta_{t}^{*}+\pi_{32} \rho_{t}+\pi_{32}^{*} \rho_{t}^{*}+\pi_{33} \mu_{t}+\pi_{33}^{*} \mu_{t}^{*}+ \\
\pi_{34} \xi_{t}+\pi_{35} m_{t-1}+\pi_{35}^{*} m_{t-1}^{*} .
\end{gathered}
$$

Journal of Economics and Business, Vol 49, No. 1 (January 1997): pg. 43-60. DOI. This article is @ Elsevier and permission has been granted for this version to appear in e-Publications@Marquette. Elsevier does not grant permission for this article to be further copied/distributed or hosted elsewhere without the express permission from Elsevier. 
Explicit and implicit solutions for the coefficients are provided in the Appendix. The exchange rate solution is provided below to facilitate the presentation of policy outcomes.

\section{Exchange Rate Solution}

After solving for the 's above, the exchange rate solution can be expressed as:

$$
\begin{gathered}
e_{t}=\left[\beta_{1}\left(\eta_{t}-\eta_{t}^{*}\right)-\delta_{1}\left(\mu_{t}-\mu_{t}^{*}\right)-\delta_{2} \xi_{t}-\delta_{3}\left(\rho_{t}-\rho_{t}^{*}\right)\right] \Delta^{-1}+m_{t-1} \\
-m_{t-1}^{*}
\end{gathered}
$$

where

$$
\begin{gathered}
\Delta \equiv-\delta_{2}\left\{\beta_{2}-\left[2-\beta_{3}\left(1-\theta_{2}\right)-\beta_{3}\left(1-\theta_{2}^{*}\right)\right]\left(\theta_{1}+\theta_{1}^{*}\right)\right\}+ \\
\beta_{1}\left[2 \beta_{5}-\beta_{6}\left(1-\theta_{2}\right)\left(\theta_{1}+\theta_{1}^{*}\right)-\beta_{6}\left(1-\theta_{2}^{*}\right)\left(\theta_{1}+\theta_{1}^{*}\right)\right]
\end{gathered}
$$

and $\beta^{\prime} s$ the $\delta^{\prime}$ and are identities provided in the Appendix.

Examining the domestic shock terms, we find that a positive domestic goods demand shock has an ambiguous effect on the exchange rate. The increased goods demand, and thus relative price effect, leads to a home currency depreciation, yet the effect of a higher interest rate leads to a home currency appreciation. If it is assumed that there is a relatively high degree of capital mobility, then $\beta_{1}<0$, and a positive goods demand shock causes a home currency appreciation. Given the assumption that the interest elasticity of bond demand exceeds the interest elasticity of money demand, a positive money demand shock causes a home currency appreciation through both the goods and portfolio channel. A positive portfolio shock, representing an exogenous shift to home bonds from foreign bonds, causes the home currency to appreciate. Finally, a positive supply shock causes the home currency to appreciate through a competitiveness effect (falling home prices make home output more competitive), to depreciate through an income effect (increased demand for foreign output), and to appreciate through a portfolio effect (similar to a money demand shock). 
As $\theta_{1}$ and $\theta_{1}^{*}$ increase (greater degree of systematic intervention), $\Delta$ increases, meaning that the exchange rate is less responsive to the shocks described above. Further, it is apparent in this solution that foreign exchange intervention affects the exchange rate, even if the intervention action is fully sterilized $\left(\theta_{2}\right.$ and $\left.\theta_{2}^{*}=1\right)$.

\section{Policy Objectives and Instrument Interaction}

The optimal exchange intervention and sterilization actions of the two policymakers are determined from the minimization of individual loss functions defined as the equally weighted average of the variance of output around its full information level and of the variance of unanticipated consumer price inflation. Thus as in Tumovsky et al. (1988), the home loss function is defined as [using equation (3)]:

$$
L=\frac{1}{2} \operatorname{Var}\left[a_{3}\left(p_{t}-E_{t-1} p_{t}\right)+\rho_{t}\right]+\frac{1}{2} \operatorname{Var}\left(c_{t}-E_{t-1} c_{t}\right)
$$

and the foreign loss function as [using equation ( $\left.3^{*}\right)$ ]:

$$
L^{*}=\frac{1}{2} \operatorname{Var}\left[a_{3}\left(p_{t}^{*}-E_{t-1} p_{t}^{*}\right)+\rho_{t}^{*}\right]+\frac{1}{2} \operatorname{Var}\left(c_{t}^{*}-E_{t-1} c_{t}^{*}\right)
$$

In many articles on optimal foreign exchange intervention, it is assumed that the home authority automatically and fully sterilizes foreign intervention and does not sterilize own intervention, and vice versa. This setup creates asymmetric money supply rules, allowing for a nash approach. However, if it is not assumed that this asymmetry automatically occurs, the money supplies and intervention coefficients are linearly dependent and a nash equilibrium does not exist. This issue is discussed and proved in Lane (1989).

Therefore, the model employed here, as that in Lane (1989), does not have a unique Nash solution for both intervention coefficients. There are an infinite number of Nash equilibrium combinations of intervention coefficients $\left(\theta_{1}\right.$ and $\left.\theta_{1}^{*}\right)$ that yield the same level of optimal intervention. Thus, it is impossible to derive unique values for both intervention coefficients. Therefore, we 
examine two cases which determine the intervention rule for one authority (as this "ties down" the value of one of the intervention coefficients) and highlight the role of sterilization policies in noncooperative contexts. Both cases use a Stackelberg approach [see Canzoneri and Henderson (1992), Chapter 2; Lane (1989)], with the home policymaker regarded as the leader (perhaps as the reserve currency country), choosing its intervention rule $\left(\theta_{1}\right)$ first. Once the intervention regime is chosen by the leader country, unique sterilization coefficients can be determined.

The first case models that where the home country determines its optimal degree of foreign exchange intervention (making intervention on the part of the foreign authority moot and thus $\theta_{1}^{*}=$ 0 ), leaving the home and foreign authorities to choose their optimal degree of sterilization. The second example considers the case where the home authority pegs the exchange rate $\left(\theta_{1}=\infty\right)$. Again, the home and foreign authority determine their sterilization actions in a noncooperative fashion.

\section{Case 1: Optimal Intervention Leader}

Initially, we consider the case where the home authority is the leader, determining its optimal degree of intervention by minimizing the loss function given in equation (14). The home and foreign authorities then determine their respective optimal degree of sterilization, considering the exchange intervention of the home authority, again minimizing the loss functions in (14) and (14*). The home authority, therefore, has two instruments with which to minimize the two-part loss function. The foreign authority, in a sense, borrows the intervention conducted by the home authority and fine tunes it with its own sterilization action.

\section{Policy Interaction}

Before computing the optimal settings for $\theta_{1}, \theta_{2}$, and $\theta_{2}^{*}$, it is worthwhile to consider the home response functions. In doing so, the strategic interaction of the home and foreign policy instruments can be determined. Using the taxonomy provided by Lane (1990), policies can be classified as strategic substitutes or strategic complements. Lane 
described foreign exchange intervention policies as strategic substitutes if intervention by one country leads to less intervention by the other country. As Lane pointed out, this case can lead to multiple equilibria, but the alternatives cannot be Pareto ranked. If foreign exchange policies are strategic complements, then intervention by one country results in greater intervention by the other country. This case leads to multiple equilibria which can possibly be Pareto ranked, and may provide for Pareto improving coordination of policies.

Marston (1980), using a two-country model of the financial sector, examined the role of sterilization policies in modifying balances of payments disturbances. Marston showed that sterilization by the (home) country conducting the intervention, reduces the variance of the home interest rate but increases the flow of foreign reserve flows. Further, sterilization by the foreign country also increases the reserve flows of the home country. This indirectly implies that home sterilization and home intervention are complementary policies, and foreign sterilization and home intervention are complementary polices. The direct relationship between foreign sterilization and home sterilization was not examined by Marston.

In the analysis here, the optimal policy response functions of the home authority result from the minimization of the home loss function, [equation (14)]. They indicate the general relationships among the three instruments. The response functions are:

$$
\theta_{2}=1-\left(1-\theta_{2}^{*}\right) \frac{\left(1+a_{3}^{2}\right) \mathrm{K}_{2}}{\left(1+a_{3}^{2}\right) \mathrm{K}_{1}+\left(\beta_{4}-\beta_{5}\right) \mathrm{K}_{3}}
$$

and

$$
\theta_{1}=\left(1-\theta_{2}^{*}\right)^{-1} \frac{\left(1+a_{3}^{2}\right) \mathrm{K}_{1}+\left(\beta_{4}-\beta_{5}\right) \delta_{3} \mathrm{~K}_{3}}{\beta_{6} \mathrm{~K}_{3}}
$$

where

$$
\begin{gathered}
K_{1} \equiv\left\{\delta_{4} \delta_{3} \sigma_{\rho}^{2}-(1-\alpha) a_{3}\left[\beta_{1} \sigma_{\eta^{*}}^{2}+a_{2} a_{4}^{-1} \delta_{1} \sigma_{\mu^{*}}^{2}+\delta_{3}(1+\right.\right. \\
\left.\left.\left.a_{2} a_{4}^{-1}\right) \sigma_{\rho^{*}}^{2}\right]\right\}
\end{gathered}
$$




$$
\begin{gathered}
K_{2} \equiv\left\{\delta_{5} \delta_{3} \sigma_{\rho}^{2}\right. \\
\left.-(1-\alpha) a_{3}\left[\beta_{1} \sigma_{\eta}^{2}+a_{2} a_{4}^{-1} \delta_{1} \sigma_{\mu}^{2}+\delta_{3}\left(1+a_{2} a_{4}^{-1}\right) \sigma_{\rho}^{2}\right]\right\}
\end{gathered}
$$

and

$$
K_{3} \equiv \delta_{3}\left\{(2 \alpha-1) \sigma_{\rho}^{2}+a_{3}^{2}\left[\alpha \sigma_{\rho}^{2}-(1-\alpha) \sigma_{\rho^{*}}^{2}\right]\right\}
$$

Equations (15) and (16) indicate a positive relationship among instruments $\left(\partial \theta_{2} / \partial \theta_{2}^{*}>0\right.$ and $\left.\partial \theta_{1} / \partial \theta_{2}^{*}>0\right)$. Hence, home sterilization policies and foreign sterilization policies are strategic complements, because increasing sterilization by the foreign authority generates greater sterilization by the home authority. To understand this relationship, consider the case where the home central bank is intervening by buying the foreign currency. This has the indirect effect of decreasing the foreign money supply and increasing the home money supply. To offset this, the foreign sterilization operation expands the foreign money supply and the home sterilization operation contracts the home money supply. However, because the foreign sterilization operation is inflationary for both economies, the home central bank must contract the home money supply by a greater extent to offset the foreign policy action and vice versa.

Foreign sterilization and home intervention are strategic complements as well; increasing sterilization by the foreign authority leads to greater intervention by the home authority. This outcome follows the logic presented above. As the foreign country offsets central bank purchases of the foreign currency, it undertakes an expansionary or inflationary policy. This, in turn, puts additional downward pressure on the foreign currency, necessitating greater purchases by the home authority.

\section{Optimal Policy}

In this section, the optimal policy solutions are derived for the three policy instruments. After substitution of the foreign reaction function into the home loss function, equation (14), the optimal setting for home intervention is:

Journal of Economics and Business, Vol 49, No. 1 (January 1997): pg. 43-60. DOI. This article is (C Elsevier and permission has been granted for this version to appear in e-Publications@Marquette. Elsevier does not grant permission for this article to be further copied/distributed or hosted elsewhere without the express permission from Elsevier. 


$$
\theta_{1}=\frac{\left[\delta_{7} \beta_{6}-\delta_{6}\left(\beta_{4}-\beta_{5}\right)\right] K_{3}+\delta_{6}\left(1+a_{3}^{2}\right)\left(K_{1}+K_{2}\right)+\beta_{6}(1-\alpha) a_{3}\left(1+a_{3}^{2}\right) K_{4}}{2 \delta_{2} \beta_{6} K_{3}}
$$

and for home sterilization

$$
\theta_{2}=1-\frac{2 \delta_{2}\left(1+a_{3}^{2}\right) K_{2}}{\delta_{6}\left(1+a_{3}^{2}\right)\left(K_{1}+K_{2}\right)+\beta_{6}(1-\alpha) a_{3}\left(1+a_{3}^{2}\right) K_{4}+\left[\delta_{7} \beta_{6}+\delta_{6}\left(\beta_{4}+\beta_{5}\right)\right] K_{3}},
$$

where

$$
K_{4} \equiv\left[\beta_{1}^{2}\left(\sigma_{\eta}^{2}+\sigma_{\eta^{*}}^{2}\right)+\delta_{3}^{2}\left(\sigma_{\rho}^{2}+\sigma_{\rho^{*}}^{2}\right)+\delta_{1}^{2}\left(\sigma_{\mu}^{2}+\sigma_{\mu^{*}}^{2}\right)+\delta_{2}^{2} \sigma_{\xi}^{2}\right]
$$

Substituting these solutions into the foreign loss function results in the optimal solution for the foreign authority's sterilization coefficient, which is:

$$
\theta_{2}^{*}=1-\frac{2 \delta_{2}\left[\left(1+a_{3}^{2}\right) K_{1}+\left(\beta_{4}-\beta_{5}\right) K_{3}\right]}{\delta_{6}\left(1+a_{3}^{2}\right)\left(K_{1}+K_{2}\right)+\beta_{6}(1-\alpha) a_{3}\left(1+a_{3}^{2}\right) K_{4}+\left[\delta_{7} \beta_{6}-\delta_{6}\left(\beta_{4}-\beta_{5}\right)\right] K_{3}} .
$$

The solutions above indicate that, in general, a managed float with incomplete sterilization is optimal. ${ }^{2}$ By examining each shock individually, the source of policy tension in this model can be highlighted. The optimal outcomes for goods demand, money demand, and portfolio shocks are provided in Table 1 below and discussed subsequently. Supply shocks are detailed individually.

For goods demand, money demand, and portfolio shocks, the optimal intervention solution is a peg, i.e., $\theta_{1}=\infty$, and the sterilization solutions are symmetric across countries. For an exogenous portfolio shift, full sterilization by both authorities is optimal. A shift in bond demand is met with a like shift in relative money supplies through the intervention action. Fully sterilizing this intervention eliminates domestic and foreign price innovations $\left[p_{t}-E_{t-1} p_{t}\right.$ and $\left.p_{t}^{*}-E_{t-1} p_{t}^{*}\right]$.

For goods demand, or money demand shocks originating from abroad, full sterilization is optimal. With the exchange rate pegged, full sterilization by the home authority makes the home price innovation equivalent to the foreign price innovation. By adjusting the foreign 
money supply (less than full sterilization by the foreign authority), the foreign authority eliminates, simultaneously, foreign and domestic price innovations. If the shock originates domestically, less than full sterilization by the home authority is optimal. The pegged exchange rate and complete sterilization by the foreign policymaker eliminates exchange rate innovations and makes foreign price innovations equivalent to home price innovations. Allowing the home money supply to adjust (less than complete sterilization) simultaneously eliminates home and foreign price innovations.

Even though an asymmetric policymaking environment exists, symmetric policy outcomes result for the shocks examined so far. This is because, without supply shocks, there are three objectives, home and foreign price innovations and the exchange rate innovation. There are also three instruments, $\theta_{1}, \theta_{2}$, and $\theta_{2}^{*}$. With the exchange rate pegged, each authority should eliminate the inflationary or deflationary consequences of shocks which originate in the domestic economy through appropriate adjustment of their money supplies. In other words, if the shock originates domestically, the domestic authority should allow the domestic money supply to adjust, i.e., not fully sterilize.

As noted earlier in the description of equation (9), $h_{2}$ and $h_{3}$ increase with greater substitutability of bonds, approaching unity in the limit. As a result, for a goods demand shock, sterilization increases also. Not as apparent, optimal sterilization increases for a money shock as well. As seen in equations (4) and (5), the money shock represents a shift from domestic bonds to domestic money. In the limit, the optimal solution for the case of a money shock is identical to that of the goods demand shock. Therefore, we find that increasing capital market integration can, in a competitive policymaking environment, lead to policies which generate greater reserve flows.

Turning to the supply shocks, we see that they are the sources of tension and asymmetry in the analysis here. The intervention solution for the foreign supply shock is $\theta_{1}=\left[h_{3} a_{4}+h_{2}+a_{2}\left(h_{3}-h_{2}\right)\right] /$ $2 a_{2} a_{3}\left(a_{4}+1\right)$. This outcome illustrates how supply shocks complicate policymaking by making an exchange rate peg suboptimal. There are now three objectives in the loss function of the home authority, home

Journal of Economics and Business, Vol 49, No. 1 (January 1997): pg. 43-60. DOI. This article is @ Elsevier and permission has been granted for this version to appear in e-Publications@Marquette. Elsevier does not grant permission for this article to be further copied/distributed or hosted elsewhere without the express permission from Elsevier. 
and foreign price innovations, and exchange rate innovations, and four in the loss function of the foreign authority, foreign output innovations, home and foreign price innovations, and exchange rate innovations. There remain, however, only three instruments. Foreign exchange intervention can no longer be directed at exchange rate innovations alone and, thus, a pegged exchange rate is suboptimal.

It is, however, still optimal for the home authority to completely sterilize, $\theta_{2}=1$, its foreign exchange intervention. However, the foreign authority now finds it suboptimal to use sterilization actions solely to smooth foreign price innovations, as foreign output will still change in light of the supply shock. The optimal degree of sterilization which results is $\theta_{2}^{*}=1-2\left[\left(1+2 a_{3}^{2}\right)\left(a_{4}+a_{2}\right)+a_{2} a_{3}\left(a_{4}+1\right)\right]\left[h_{3} a_{4}+\right.$ $\left.h_{2}+a_{2}\left(h_{3}-h_{2}\right)\right]^{-1}$. For these outcomes, greater bond substitutability increases the optimal degree of intervention, driving $\theta_{1}$ to infinity (pegged rate) in the limit. Further, greater substitutability increases the optimal degree of foreign sterilization, reaching complete sterilization in the limit $\theta_{2}^{*}=1$.

The optimal solutions in light of a foreign supply shock are more complicated and given in equations (20)-(22). The optimal intervention solution is:

$$
\theta_{1}=\frac{K_{5}}{2 a_{2}\left(a_{4}+1\right)\left[(2 \alpha-1)+\alpha a_{3}^{2}\right]^{\prime}}
$$

where

$$
\begin{aligned}
& K_{5} \equiv a_{4}\left[a_{3}^{2} \alpha+(2 \alpha-1)\right]\left[\beta_{6}\left(\beta_{2}-\beta_{1}\right)+\beta_{3}\left(\beta_{5}-\beta_{4}\right)\right]+ \\
& a_{4} \delta_{6}\left(1+a_{3}^{2}\right)+\left(1+a_{3}^{2}\right) a_{3}(1-\alpha)\left[\beta_{6} h_{2}-\beta_{3}\left(a_{4}+a_{2}\right)\right]
\end{aligned}
$$

Equation (20) shows that the home authority allows partial adjustment for this shock as well. The solution for the optimal degree of home sterilization is:

$$
\theta_{2}=1-\frac{2\left(1+a_{3}^{2}\right)\left[a_{1} a_{4}+(1-\alpha) a_{2}\right]}{K_{5}}
$$

Journal of Economics and Business, Vol 49, No. 1 (January 1997): pg. 43-60. DOI. This article is @ Elsevier and permission has been granted for this version to appear in e-Publications@Marquette. Elsevier does not grant permission for this article to be further copied/distributed or hosted elsewhere without the express permission from Elsevier. 
and for foreign sterilization,

$$
\theta_{2}^{*}=1-\frac{2\left[\beta_{4}+a_{2}^{2} \beta_{5}+\left(2 a_{3}^{2}+1\right) \alpha\left(\beta_{4}-\beta_{5}\right)\right]}{K_{5}}
$$

When the supply shock originates in the home economy, the home authority uses its exchange rate intervention and sterilization operations to export the effects of the supply shock. The foreign authority must respond by adjusting its money supply (less than full sterilization). Increasing substitutability of bonds again increases the optimal degree of intervention, leading to a pegged rate $\left(\theta_{1}=\infty\right)$ with perfect substitutability. Also, the optimal degree of sterilization increases with increased substitutability of bonds, with full sterilization optimal in the limit $\left(\theta_{2}\right.$ and $\left.\theta_{2}^{*}=1\right)$.

This leader-intervention case reveals the competitive relationship of sterilization policies and intervention policies. Increased sterilization by the foreign authority generates greater sterilization and intervention by the home authority. As demonstrated by Marston (1980), this relationship between sterilization and intervention can cause greater variability of reserves. The positive relationship between sterilization policies is established here and adds even further to the problem of reserve instability.

It is also shown here that increased international substitutability of assets compounds this problem. With perfect capital mobility, $h_{2}$ and $h_{3}$ approach infinity, as explained below equation (9). As a result, the loss functions described in equations (14) and $\left(14^{*}\right)$ reduce to three elements, home price innovations, foreign price innovations, and exchange rate innovations. The loss functions of the two authorities are minimized when the exchange rate is pegged, and money supplies are (trend) stationary, which comes about with full sterilization. The case where the leader pegs the exchange rate is examined next. 


\section{Case 2: Fixed Exchange Rate Leader}

In this second case, it is assumed that the home authority elects to peg the exchange rate. Therefore, $\theta_{1}=\infty$. The optimal sterilization coefficients of the home and foreign authorities are determined, taking $\theta_{1}=\infty$ as given, in a competitive manner. The reaction functions which result in this case display the same relationship between instruments as in the first case; that is, home and foreign sterilization operations are strategic complements. Because of space consideration they are not provided here.

The optimal sterilization coefficients for the home and foreign authorities are:

$$
\begin{gathered}
\theta_{2}=1-2 \\
\frac{\delta_{2}\left\{(2 \alpha-1)\left(\alpha+a_{3}^{2}\right) K_{6}+a_{3} \delta_{3}\left[\left(\alpha \delta_{5}+a_{3}^{2} \beta_{5}\right) \sigma_{\rho^{*}}^{2}+\left(\alpha \delta_{4}+a_{3}^{2} \beta_{4}\right) \sigma_{\rho}^{2}\right]\right\}}{\left(\alpha+a_{3}^{2}\right)\left\{(2 \alpha-1)\left[\beta_{6} K_{4}-\delta_{6}\left(K_{6}+K_{7}\right)\right]+\delta_{2} \delta_{6} a_{3} \delta_{3}\left(\sigma_{\rho}^{2}+\sigma_{\rho^{*}}^{2}\right)\right\}}
\end{gathered}
$$

and

$$
\begin{gathered}
\theta_{2}=1-2 \\
\frac{\delta_{2}\left\{(2 \alpha-1)\left(\alpha+a_{3}^{2}\right) K_{7}+a_{3} \delta_{3}\left[\left(\alpha \delta_{5}+a_{3}^{2} \beta_{5}\right) \sigma_{\rho}^{2}+\left(\alpha \delta_{4}+a_{3}^{2} \beta_{4}\right) \sigma_{\rho^{*}}^{2}\right]\right\}}{\left(\alpha+a_{3}^{2}\right)\left\{(2 \alpha-1)\left[\beta_{6} K_{4}-\delta_{6}\left(K_{6}+K_{7}\right)\right]+\delta_{2} \delta_{6} a_{3} \delta_{3}\left(\sigma_{\rho}^{2}+\sigma_{\rho^{*}}^{2}\right)\right\}}
\end{gathered}
$$

where

$$
K_{6}=\beta_{1} \sigma_{\eta}^{2}+a_{2} a_{4}^{-1} \delta_{1} \sigma_{\mu}^{2}+\delta_{3}\left(1+a_{2} a_{4}^{-1}\right) \sigma_{\rho}^{2}
$$

and

$$
K_{7}=\beta_{1} \sigma_{\eta^{*}}^{2}+a_{2} a_{4}^{-1} \delta_{1} \sigma_{\mu^{*}}^{2}+\delta_{3}\left(1+a_{2} a_{4}^{-1}\right) \sigma_{\rho^{*}}^{2}
$$

As in the previous case, the solutions above show, in general, optimal sterilization to be less than complete. Considering the outcome for specific shocks, we find the solutions for goods demand, money demand and portfolio shocks to be identical to the previous case. This 
outcome is logical because, for these particular shocks, it was optimal for the home authority to peg the exchange rate as it is here.

The supply shocks, however, yield quite different solutions. For a home country supply shock, the optimal sterilization coefficients are:

$$
\theta_{2}=\frac{2 a_{4}\left[(2 \alpha-1)\left(a_{2}+a_{4}\right)+\delta_{2} a_{4} a_{3}\right]}{(2 \alpha-1)\left[a_{2}\left(1+a_{4}\right) h_{2}-\left(h_{2}+h_{3} a_{4}\right)\left(a_{2}+a_{4}\right)\right]+\delta_{6} a_{4}^{2} a_{3}}
$$

and

$$
\theta_{2}^{*}=\frac{2 \delta_{2} a_{4} a_{3}}{(2 \alpha-1)\left[a_{2}\left(1+a_{4}\right) h_{2}-\left(h_{2}+h_{3} a_{4}\right)\left(a_{2}+a_{4}\right)\right]+\delta_{6} a_{4}^{2} a_{3}}
$$

The solution for $\theta_{2}$ is different than in the first case as the exchange rate is being pegged by the home authority as opposed to managed; nonetheless, the home authority finds partial sterilization to be optimal. Likewise, less than full sterilization is optimal for the foreign authority. As in the previous outcomes, the optimal degree of home sterilization increases with greater international substitutability of assets, approaching unity in the limit.

For a foreign country supply shock, the optimal degree of sterilization coefficients for the home and foreign authorities are symmetric to those above, contrasting the competitive case with the leadership case described previously. ${ }^{3}$ As in the previous case, though, less than full sterilization is, in general, optimal.

\section{Summary and Conclusion}

In this paper, the optimal sterilization procedures have been determined for two-country leadership flexible and leadership fixed exchange-rate regimes. These solutions indicate that, in general, less than full sterilization is optimal. It also has been shown that sterilization policies are strategic complements between the two countries and strategic complements with intervention policies. 
Therefore, in a competitive policymaking environment, greater use of sterilization leads to both increased sterilization by the other authority and greater exchange intervention. The result is increased reserve flows and possibly explosive reserve flows [Mastropasqua et al. (1988, p. 270)]. Greater substitutability of assets internationally generates further sterilization and, therefore, compounds this problem.

The somewhat common practice of automatic and complete sterilization of own and other country interventions should therefore be questioned, even in an environment where sterilized intervention is (theoretically) effective. Given that sterilization policies are strategic complements, it may be possible to coordinate sterilization policies and avoid excessive reserve variability. This issue is, however, beyond the scope of analysis presented here.

\section{Acknowledgments}

This paper has benefitted greatly from valuable suggestions and criticisms from David D. VanHoose, Farrokh Nourzad, Peter Toumanoff, and two anonymous referees.

\section{Notes}

1. The various ways in which exchange market intervention is conducted and financed is detailed in Humpage (1994). What is envisioned here is intervention along the lines of the example in Batten and Ott (1984).

2. Given the symmetry assumed in the model and loss functions examined here, if the home authority were to surrender intervention to the foreign authority, the optimal instrument settings which would result would be symmetric to those of the first case.

3. Solutions for a pegged-rate regime, where the home authority acts as a leader in determining the optimal degree of sterilization, are available from the author upon request.

\section{References}

Batten, D. S., and Ott, M. May 1984. What can central banks do about the value of the dollar? Federal Reserve Bank of St. Louis Review 66(3):16-26.

Journal of Economics and Business, Vol 49, No. 1 (January 1997): pg. 43-60. DOI. This article is @ Elsevier and permission has been granted for this version to appear in e-Publications@Marquette. Elsevier does not grant permission for this article to be further copied/distributed or hosted elsewhere without the express permission from Elsevier. 
NOT THE PUBLISHED VERSION; this is the author's final, peer-reviewed manuscript. The published version may be accessed by following the link in the citation at the bottom of the page.

Benavie, A Apr. 1983. Achieving external and internal targets with exchange rate intervention. Journal of International Money and Finance 2(1):7585.

Benavie, A, and Froyen, R. Nov. 1992. Optimal monetary and exchange rate policy with a two-tier exchange rate. Journal of Economics and Business 44(4):283-300.

Black, S. W. 1985. The effect of alternative intervention policies on the variability of exchange rates: The Harrod effect. In Exchange Rate Management Under Uncertainty (J. Bhandari, ed.). Cambridge, MA: MIT Press, pp. 73-82.

Bordo, M. D., and Schwartz, A J. Jan. 1991. What has foreign exchange market intervention since the Plaza Agreement accomplished? Open Economies Review 2(1):39-64.

Boyer, R. S. Dec. 1978. Optimal foreign exchange market intervention. Journal of Political Economy 86(61):1045-1055.

Branson, W. H., and Henderson, D. W. 1985. Specification and influence of asset markets. Handbook of International Economics, Vol. 2 (R. W. Jones and P. B. Kener, eds.). New York: North-Holland, pp. 750-782. Canzoneri, M. B. Nov. 1982. Exchange rate intervention policy in a multiple country world. Journal of International Economics 13(3/4):267-290.

Canzoneri, M. B., and Henderson, D. W. 1992. Monetary Policy in Interdependent Economies: A Game Theoretic Approach. Cambridge, MA: MIT Press.

Dominguez, K., and Frankel, J. A 1993. Does Foreign Exchange Intervention Work? Washington, DC: Institute for International Economics.

Gros, D., and Lane, T. Jan. 1992. Monetary policy interaction within or without and exchange rate arrangement. Open Economies Review 3(1):61-82.

Herring, R. J., and Marston, R. C. Dec. 1977. Sterilization policy: The tradeoff between monetary autonomy and control over foreign exchange reserves. European Economic Review 10(3):325-343.

Humpage, O. F. 1994. Institutional aspects of U.S. intervention. Federal Reserve Bank of Cleveland, Economic Review 30(1):2-19.

Jones, M. Feb. 1983. International liquidity: A welfare analysis. Quarterly Journal of Economics 98(1):1-23.

Kenen, P. B. 1982. Effects of intervention and sterilization in the short run and the long run. In The International Monetary System Under Flexible Exchange Rates (R. Cooper and R. Triffin, eds.). Cambridge: Ballinger Publishing Co., pp. 51-68.

Lane, T. D. Nov. 1990. National sovereignty and international monetary order. Journal of International Economics 29(3/4):351-368.

Journal of Economics and Business, Vol 49, No. 1 (January 1997): pg. 43-60. DOI. This article is @ Elsevier and permission has been granted for this version to appear in e-Publications@Marquette. Elsevier does not grant permission for this article to be further copied/distributed or hosted elsewhere without the express permission from Elsevier. 
Lane, T. D. Fall 1989. Foreign exchange market intervention in interdependent economies: A case for capricious policy? Journal of Macroeconomics 11(4):513-531.

Marston, R. C. Feb. 1980. Cross country effects of sterilization, reserve currencies, and foreign exchange intervention. Journal of International Economics 10(1):63-78.

Natividad, F., and Stone, J. A. Aug. 1990. A general equilibrium model of exchange market intervention with variable sterilization. Journal of International Economics 29(1/2): 133-145.

Obstfeld, M. Mar./Apr. 1983. Exchange rates, inflation and the sterilization problem. European Economic Review 21(1/2):161-189.

Pasula, K. Fall 1994. Sterilization, Ricardian equivalence and structural and reduced-form estimates of the offset coefficient. Journal of Macroeconomics 16(4):683-699.

Turnovsky, S. J., Basar, T., and d'Orey, V. June 1988. Dynamic strategic monetary policies and coordination in interdependent economies. The American Economic Review 78(3):341-361.

Turnovsky, S. J. Apr. 1985a. Domestic and foreign disturbances in an optimizing model of exchange-rate determination. Journal of International Money and Finance 1(1):151-171.

Turnovsky, S. J. 1985b. Optimal exchange market intervention: Two alternative classes of rules. In Exchange Rate Management under Uncertainty (J. Bhandari, ed.). Cambridge, MA: The MIT Press, pp. 5572.

von Hagen, J. Sept./Oct. 1989. Monetary targeting with exchange rate constraints: The Bundesbank in the 1980s. The Federal Reserve Bank of St. Louis Review 71(5):53-69.

\section{Appendix}

\section{Model Solutions}

$$
\begin{gathered}
P_{t}=\pi_{10}+\pi_{11} \eta_{t}+\pi_{11}^{*} \eta_{t}^{*}+\pi_{12} \rho_{t}+\pi_{12}^{*} \rho_{t}^{*}+\pi_{13} \mu_{t}+\pi_{13}^{*} \mu_{t}^{*} \\
+\pi_{14} \xi_{t}+\pi_{15} m_{t-1}+\pi_{15}^{*} m_{t-1}^{*} \\
P_{t}^{*}=\pi_{20}+\pi_{21} \eta_{t}+\pi_{21}^{*} \eta_{t}^{*}+\pi_{22} \rho_{t}+\pi_{22}^{*} \rho_{t}^{*}+\pi_{23} \mu_{t}+\pi_{23} \mu_{t}^{*} \\
+\pi_{24} \xi_{t}+\pi_{25} m_{t-1}+\pi_{25}^{*} m_{t-1}^{*} \\
e_{t}=\pi_{30}+\pi_{31} \eta_{t}+\pi_{31}^{*} \eta_{t}^{*}+\pi_{32} \rho_{t}+\pi_{32}^{*} \rho_{t}^{*}+\pi_{33} \mu_{t}+\pi_{33}^{*} \mu_{t}^{*} \\
+\pi_{34} \xi_{t}+\pi_{35} m_{t-1}+\pi_{35}^{*} m_{t-1}^{*}
\end{gathered}
$$

Journal of Economics and Business, Vol 49, No. 1 (January 1997): pg. 43-60. DOI. This article is @ Elsevier and permission has been granted for this version to appear in e-Publications@Marquette. Elsevier does not grant permission for this article to be further copied/distributed or hosted elsewhere without the express permission from Elsevier. 
NOT THE PUBLISHED VERSION; this is the author's final, peer-reviewed manuscript. The published version may be accessed by following the link in the citation at the bottom of the page.

$$
\begin{aligned}
& \pi_{10}=\pi_{20}=\pi_{30}=0 \\
& \pi_{15}=\pi_{25}^{*}=\pi_{35}=1, \pi_{25}=\pi_{15}^{*}=0, \pi_{35}^{*}=1 \text {, } \\
& \pi_{16}=\pi_{26}^{*}=\pi_{36}=1, \pi_{26}=\pi_{16}^{*}=1, \pi_{36}^{*}=1 \text {, } \\
& \pi_{11}=\left\{\beta_{4}\left[\beta_{2}+2-\left(2-\theta_{2}-\theta_{2}^{*}\right)\left(\theta_{1}+\theta_{1}^{*}\right)\right]\right. \\
& \left.-\beta_{1}\left[2-\beta_{3}\left(1-\theta_{2}\right)-\beta_{3}\left(1-\theta_{2}^{*}\right)\right]\left(\theta_{1}+\theta_{1}^{*}\right)\right\} \Delta^{-1} \\
& \pi_{11}^{*}=\left\{\beta_{5}\left[\beta_{2}+2-\left(2-\theta_{2}-\theta_{2}^{*}\right)\left(\theta_{1}+\theta_{1}^{*}\right)\right]\right. \\
& \left.-\beta_{1}\left[2-\beta_{3}\left(1-\theta_{2}\right)-\beta_{3}\left(1-\theta_{2}^{*}\right)\right]\left(\theta_{1}+\theta_{1}^{*}\right)\right\} \Delta^{-1} \\
& \pi_{12}=-a_{2} a_{4}^{-1} \pi_{11}-\left(1-h_{2} a_{4}^{-1}\right) \pi_{13} \\
& \pi_{12}^{*}=-a_{2} a_{4}^{-1} \pi_{11}^{*}-\left(1-h_{2} a_{4}^{-1}\right) \pi_{13} \\
& \pi_{13}=-\left\{\left(\beta_{4}-\beta_{5}\right)-\left[\beta_{4}\left(1-\theta_{2}\right)-\beta_{5}\left(1-\theta_{2}^{*}\right)\right]\left(\theta_{1}+\theta_{1}^{*}\right)\right\} \Delta^{-1} \\
& \pi_{14}=-\left(1+a_{2} a_{4}^{-1}\right) \pi_{11} \\
& \pi_{14}^{*}=-\left(1+a_{2} a_{4}^{-1}\right) \pi_{11}^{*} \\
& \pi_{21}=\pi_{11}^{*} \\
& \pi_{21}^{*}=\pi_{11} \\
& \pi_{22}=-a_{2} a_{4}^{-1} \pi_{21}-\left(1-h_{2} a_{4}^{-1}\right) \pi_{13} \\
& \pi_{22}^{*}=-a_{2} a_{4}^{-1} \pi_{21}^{*}-\left(1-h_{2} a_{4}^{-1}\right) \pi_{13} \\
& \pi_{23}=-\left\{\left(\beta_{5}-\beta_{4}\right)-\left[\beta_{5}\left(1-\theta_{2}\right)-\beta_{4}\left(1-\theta_{2}^{*}\right)\right]\left(\theta_{1}+\theta_{1}^{*}\right)\right\} \Delta^{-1}
\end{aligned}
$$




$$
\begin{aligned}
& \pi_{24}=-\left(1+a_{2} a_{4}^{-1}\right) \pi_{21} \\
& \pi_{24}^{*}=-\left(1+a_{2} a_{4}^{-1}\right) \pi_{21}^{*} \\
& \pi_{31}=-\pi_{31}^{*}=\beta_{1} \Delta^{-1} \\
& \pi_{32}=-\pi_{32}^{*}=-\left(1+a_{2} a_{4}^{-1}\right) \pi_{31}+h_{2} a_{4}^{-1} \pi_{33} \\
& \pi_{33}=-\pi_{33}^{*}=-a_{2} a_{4}^{-1} \pi_{31}+\left(1-h_{2} a_{4}^{-1}\right) \pi_{33} \\
& \pi_{34}=-\left(\beta_{4}+\beta_{5}\right) \Delta^{-1} \\
& \quad+\beta_{1}\left[2 \beta_{5}-\beta_{6}\left(1-\theta_{2}\right)\left(\theta_{1}+\theta_{1}^{*}\right)\right. \\
& \left.\quad-\beta_{6}\left(1-\theta_{2}^{*}\right)\left(\theta_{1}+\theta_{1}^{*}\right)\right]
\end{aligned}
$$

\section{Identities}

$$
\begin{aligned}
& \beta_{1} \equiv h_{1}-h_{2} a_{4}^{-1}\left(1+a_{3}\right) \\
& \beta_{2} \equiv h_{1}+h_{3} \\
& \beta_{3} \equiv h_{2} a_{4}^{-1}+h_{3} \\
& \beta_{4} \equiv a_{3}+a_{1}+a_{2} a_{4}^{-1}\left(1+a_{3}\right)+\alpha a_{2} \\
& \beta_{5} \equiv a_{1}-(1-\alpha) a_{2} \\
& \beta_{6} \equiv a_{2}\left(1+a_{4}^{-1}\right) \\
& \beta_{7} \equiv\left(\beta_{4}^{2}-\beta_{5}^{2}\right) \\
& \delta_{1} \equiv \beta_{1} a_{2} a_{4}^{-1}-\left(\beta_{4}+\beta_{5}\right)\left(1-h_{2} a_{4}^{-1}\right)
\end{aligned}
$$


$\delta_{2} \equiv \beta_{4}+\beta_{5}$

$\delta_{3} \equiv \beta_{1}\left(1+a_{2} a_{4}^{-1}\right)+\left(\beta_{4}+\beta_{5}\right) h_{2} a_{4}^{-1}$

$\delta_{4} \equiv \alpha \beta_{4}+(1-\alpha) \beta_{5}$

$\delta_{5} \equiv(1-\alpha) \beta_{4}+\alpha \beta_{5}$

$\delta_{6} \equiv \beta_{1} \beta_{6}+\delta_{2} \beta_{3}$

$\delta_{7} \equiv \beta_{2} \delta_{2}-2 \beta_{1} \beta_{5}$

\section{Table 1}

\begin{tabular}{cccc}
\hline Shock & $\theta_{1}$ & $\theta_{2}$ & $\theta_{2}^{*}$ \\
\hline$\eta_{t}$ & $\infty$ & $1-2 a_{4} /\left(h_{2}+a_{4} h_{3}\right)$ & 1 \\
$\eta_{t}^{*}$ & $\infty$ & 1 & $1-2 a_{4} /\left(h_{2}+a_{4} h_{3}\right)$ \\
$\mu_{t}$ & $\infty$ & $1-2 /\left(1+a_{4}+h_{3}-h_{2}\right)$ & 1 \\
$\mu_{t}^{*}$ & $\infty$ & 1 & $1-2 /\left(1+a_{4}+h_{3}-h_{2}\right)$ \\
$\xi_{t}$ & $\infty$ & 1 & 1 \\
\hline
\end{tabular}

